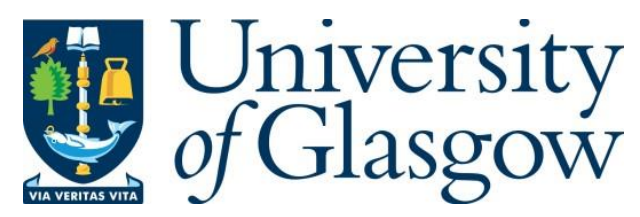

Bouzanis, C. and Panos, G. (2017) Greece, Financialization and the EU: The Political Economy of Debt and Destruction, By: Vassilis K. Fouskas and Constantine Dimoulas, Palgrave Macmillan July 2013. Journal of General Management, 42(4), pp. 92-95.

There may be differences between this version and the published version. You are advised to consult the publisher's version if you wish to cite from it.

http://eprints.gla.ac.uk/135860/

Deposited on: 18 December 2017

Enlighten - Research publications by members of the University of Glasgow http://eprints.gla.ac.uk 


\title{
Greece, Financialization and the EU: The Political Economy of Debt and Destruction: Book Review
}

\author{
Christoforos Bouzanis and Georgios A. Panos ${ }^{\dagger}$
}

This review offers an overview of the textbook, titled "Greece, Financialization and the EU: The Political Economy of Debt and Destruction" (2013, Palgrave), by Dimoulas and Fouskas. The book is available in Serbian, Croatian and Greek in more recent editions. Founded on analytical tools from geopolitics, international relations, sociology and political economy, the authors embark on an exciting journey that intends to provide a critical viewpoint on the specifics on the Greek debt crisis. We have found the analysis of the book as a most illuminating primer on the modern Greek tragedy, an important complementary tool in its analysis, and as a most useful text in the shelf of crisis analysts.

This is an intuitive book that attains a systematic historical approach to the so called modern 'Greek drama', while presenting it as a characteristic example of the intrinsic contradictions, asymmetries and antinomies of contemporary global capitalist relations. It is in this sense that we take this analysis to contribute to the existing literature of the post-Marxist international political economy in a twofold way: it offers a theoretical contribution and a case study. The former refers to the emphasis on geo-politics and geo-strategy of security that are factors which contribute to the formulation and transformation of the structure of the global flows and uneven development of the capital. Then, Greece is a characteristic case study as a country of the periphery of the European Union, that is placed in this structure of dependency and exploitation. However, the authors also underline the role of neo-liberalism in the discursive formulation of local and regional elites in the periphery and semi-periphery. These elites participate in the ideological legitimization of those practices that sustain the structures of dependency, in the form of global/regional fault-lines that both expand and undermine the contemporary formulation of the capital.

Following these lines, the authors are very careful in coming to terms with recent tendencies in social theory and the related focus on the indeterminacy of agential intervention in socio-cultural transformation. For them, agency is as important as structure, since their analysis constitutes an insightful theoretical struggle in reconciling the notion of structural tendency with the idea that various agencies - including bureaucracies of the state as well as investors and political parties - can take geo-strategic political and/or economic decisions that can transcend immediate class interest. Yet, the authors take a more radical step in their multifactored analysis of the capital formation and re-formulation: 'Global fault-lines are the discursive articulation of economic, political, ideational and geo-political instances in a social struggle' (Fouskas and Dimoulas, 2013: 44). The idea of the discursive formulation of institutional and structural social forms is, according to our view, an insightful contribution of

\footnotetext{
Corresponding author: Christoforos.Bouzanis@glasgow.ac.uk

* Dr. Bouzanis is a post-doctoral research fellow and Prof. Panos is a professor if finance at the Adam Smith Business School of the University of Glasgow.
} 
the authors to an ongoing revealing discussion on global and regional structures of dependency and their ontological relation with ideational and cultural elements. Whether post-Marxism can allow for this discursive construction is a future theoretical challenge.

The first part of the book offers a theoretical overview on financialization and the European integration process. In Chapter 2, the authors explain that their focal point is to present the ways in which debt and its formulation are a constituent part of the crises of modern capitalism - the ways in which the state and the dominant class fraction in the periphery are related in a structural mode of asymmetrical circulation of values. This takes the form of an international apparatus of uneven development and exploitation that is strategically and ideologically guided by the centre/core. Indeed, ideological orientations are not without a role in this global terrain of uneven development, since, the authors do not fall into the trap of overdetermination in a base/superstructure schema and, instead, underline the theoretical need to incorporate in our analyses the ways in which the ideological pervasiveness of neoliberalism and the omnipresent relevance of geopolitics are part and parcel of the organic whole of modern capitalism and of its periodic crises. In this picture, credit and debt constitute the hydraulics of the production, reproduction and expansion of both real and fictitious values.

It is at this point that one should clarify that the authors follow Marx's theory of value in their analysis of money, production, distribution and debt. In this context, by the term 'fictitious capital' the authors point to the money that does not correspond to the real production of value by the workers, and which enables capitalism to survive, because of the partial revival of investment that this fictitious money enables. This remark casts light on what the authors call the 'sinews of capital': ideology, geopolitics, commodity production and distribution and fictitious financial/credit practices, as well as governmental semi-dependent relevant activity in a global terrain consisting of various structures and agencies. These set the apparatus of modern capitalism in motion. It is in this sense, that the idea of the sinews of capital supports later Marx's nomology of tendencies rather than a crude materialistic form of economism. Therefore, the resulting political economy of debt underlines state security as one of the various factors that co-determinate the structure of capital formulations and their flows in a global terrain.

As we shall show later, these remarks enable the authors to proceed to an insightful multi-factored assessment of what really happened in the so called 'modern Greek drama'. This assessment is conducted in relation to the geo-strategic position of Greece, its historical and cultural specificities and its status as a dependent state of the periphery of the modern global scenery, which comprises of relations of uneven development. For the moment, the distinction between real and fictitious capital becomes crucial for the analysis of the intrinsic production of crises. It is also crucial for the analysis of the ways in which different agencies and the faultlines they follow struggle to control them. Following David Harvey, a prominent author in the Marxist tradition of the historical analysis of capitalism, the authors think that this distinction can enhance our efforts to complement Marx's theory of crises and over-accumulation of capital with the tracing of the paths that the credit and debt creation have taken in modern capitalism.

On this, the authors follow the distinction between financial capital and finance capital. The former refers to that latter stage of capitalist development, at which globalization entails an extreme tendency of credit institutions and banks to intervene to - and up to a point, to 
overshadow - the real economy. This is performed primarily via the introduction of complex practices and activities, which indicate the lack of commitment of this form of capital to the material production of value and surpluses. Thus, unlike finance capital, which was supposed to enable the expansion of the material conditions of the capitalist mode of production, this new form of capital both expands itself and undermine material production in the era of extreme financialization. This process defines what the authors call financialization or creditism. In this era, the debts and deficits, which the viciously circular path that financial capital follows via the generation of bubbles, are transferred to the tax-payers of the lower classes through the intervention of the state. It is at this point that the authors imply that in the era of financialization, neoliberalism goes hand in hand with higher-levels of taxation and other forms of domination, or violent state intervention.

Yet, the analysis of the authors shows that not all states can be equally placed at the same level of risk towards this catastrophic movement of financial capital. While capitalism is likely to be undermined by malignant practices, the countries of the core can still take the advantage of the global flows of this form of uncontrolled credit: "the core is exporting capital goods and advanced commodities, whether "real" or "fictitious", and the periphery is importing them' (Fouskas and Dimoulas, 2013:27). It is at this point that the authors refer to the differences in prices between Germany and Greece in the shared monetary zone of the Euro. Germany here attains a hegemonic role because of its central position in a monetary structure, which allows for a mode of neo-colonial strategies among the countries that are positioned within it.

The authors also refer to the higher inflation rate of Greece, compared to the one of Germany, as well as the Germany's tactic of wage freezing that rendered the exported commodities of the latter more antagonistic within the monetary union. This practice means that the difference cannot be 'corrected' through modification in the currency differentials, and thus, one ends up with the creation of trade deficits. However, what is missing from this account is a more extensive analysis of the differences of productivity among the countries of the Eurozone. The problem is that these differences cannot be theorised in terms of Marx's theory of value, because of its homogenizing aspect regarding the correspondence between the working hours that are needed to produce a good and the number of items that are produced.

All in all, Fouskas and Dimoulas' analysis casts light on the exploitation of the periphery from the core by means of deficit-production, and subsequently, of debt-creation in a global deleterious context of the relatively autonomized financial capital, the flows of which have been disoriented from material and/or geographical expansion.

What is really interesting and academically intriguing at this point is that the authors recognize that imperialism can appear both in capitalist and pre-capitalist societies. Interestingly, the authors cast a historical gaze on the common characteristics of empires that proceeded in a form of financial expansion at the stage of development which was characterized by economic deceleration. Does systemic crisis lead to plasmatic stabilization as a mediatory stage that pre-dates the final decline of an empire? We believe that the authors lean towards giving a positive answer to this question, while remaining careful in sustaining a nondeterminist stance towards history. More specifically, such a non-deterministic stance is maintained towards the unpredictable forms that the capital might take in its co-production with culture, ideology, geo-politics and semi-independent institutions like the state. 
Chapter 3 embarks on the second part of the book, offering a unique synthesis of insights into Greece's fault lines and the political economy of debt. The analysis reviews the socio-political developments in Greece, starting from the foundation of the Greek state in 1830 and up to the German occupation of the country by the Nazi troops. The authors start their analysis by making clear that the birth of the Greek state was permitted by European powers for specific geo-strategic reasons. A new state that is subordinated to Britain and France could both set new boundaries to the Ottoman empire and control the Russian and Egyptian aspirations in the eastern Mediterranean. According to the authors, this is the first and foremost fault-line of Greece. Thus, being a vassal subservient to the lord that had freed it, Greece had never had the level of independence that would allow taking full own initiative and exploiting its geo-strategic position. Its economy retained an agricultural character, resulting to Greece importing industrial goods and technology, while exporting mostly agricultural products. The authors argue this is Greece's second fault line. This partially explains the persistent trade deficits, as well as the continuous borrowing requirements which lead to excessive debt creation and subsequent defaults. However, there were also internal reasons for excessive borrowing and debt creation. The Greek political system remained in a bi-polar kampfplatz which, according to the authors, contributed to and exacerbated the fault-lines discussed above, since the conflict between the liberal/modernizing faction and the conservative/populist one constituted a political phenomenology that guaranteed the prominence of the anti-communist discourses.

In follow-up Chapter 4 , the authors discuss how the retreat of the Nazi troops left a ruined country with destructed economic structures, with the situation becoming even worse after the subsequent civil war. As the authors argue in this chapter, Greece's reconstruction would never have happened if the position of the country was not so crucial for security issues during the cold war. The authors claim that, after the defeat of the communist movement by the nationalist forces in 1949, Greece underwent through a new phase of patronism from abroad. As the authors explain, the new supervising force had two supervisees helping it in the anti-Soviet geo-political game in the area of eastern Mediterranean: Greece and Turkey. Yet, Turkey appeared in the eyes of the geo-strategy designers as more crucial for the anti-Stalinist line, as well as having broader territorial depth. It is in this sense, that in order to favour Turkey's special geo-political demands in the Aegean, it was shown the green light for the dichotomisation of Cyprus.

The authors analyse how this direct foreign interference in Greece was perpetuated with 'sophisticated' methods. What the authors call the Greek kampfplatz, as the political phenomenology that render the anti-communist discourses prevalent, was not only supported by foreign agencies, but also by local political and economic elites that set their financial interests in line with the interests of the foreign capital. It was in such a toxic environment that Andreas Papandreou's (a persona that had a central role in the political kampfplatz of that period) attempt to radicalize the discussion of the public requirement for a democratic reform in the 1960s led to the dictatorship of the Colonels, which arguably took place with support from abroad. This demarcated a constitutional rapture that lasted almost seven years, ending up with the invasion of Turkey to Cyprus, but also an era in which Greece remained tied to the interests of the advanced core. Thus, in spite of the economic growth in the 1950s and 1960s, 
the Greek economy never managed to 'catch up' with the technological supremacy of the countries of the core.

In $\underline{\text { Chapter } 5}$, the authors explain why Greek state elites failed, in the period after the dictatorship of the colonels, to follow the general fault-lines of financialization that the countries of the core followed towards a new globalized world order. The popular movement requiring democratic participation, geo-political issues related to Cyprus (leading to defence spending) and the poor industrial economic structure of Greece were proved to be important impulses for those elites to follow a peculiar clientistic Keynsianism, in a period in which the countries of the north implemented wage cuts, privatizations and welfare state retrenchment in view of the stagflagation of the 1970s. The dominant parties of the political kampfplatz of this period in Greece, promoted - or failed to prevent - policies of nationalization, extensive expenditure and borrowing. These were all primarily responsible for debt creation, which eventually led to the formation of a state-aided middle class that attained a parasitic status. These were all contributing forces to the undercutting of the power of the labour movement. As the authors note, it is at this historical stage that the dependency of the Greek economy moves from US post-war capital to EU subsidies and loans. Yet, Greek-style clientelism survived even after mid-1990s, i.e. after the Greek economy adopted financialization. Funding coming from EU programmes and wider borrowing possibilities led to the formation of a finance-oriented comprador class, with the result that the poor industrial structure of production of the Greek economy remained the case.

In $\underline{\text { Chapter } 6}$, the authors start the analysis by arguing for a power transition from USA and the West to the 'global East'. They claim that neo-liberal economics cannot account for this transition, which had its origins in the decline of profitability that took place due to competition among US, European and Japanese capitalists. In this unstable global environment, the countries of the periphery that are dependent on the financial importation of fictitious capital from the core are even more vulnerable to capital fluctuations and systemic crises. More specifically, the case for the Greek economy is that its internal structure discussed above contributed to making the path towards the current debt crisis. The bipolarised political kampfplatz of PASOK and ND led to a continuously growing gap between real production of value and the import of inflationary money (debt), to sustain an emerging finance-oriented bourgeoisie. Therefore, it is clear that the authors adopt a multifactorial theorisation of the Greek case, in the sense that both external and internal factors are assumed to induce the Greek debt crisis. In addition, the authors provide a revealing and illuminating empirical and comparative analysis in showing this.

The authors argue, the Greek prime-minister Costas Simitis' 'modernisation' programmatic agenda, which was implemented between 1996-2004, was actually nothing more than a further deepening stage of financialization of the Greek economy and the ruling elites. This agenda was succeeding practices of populism and clientism by PASOK in the years of Andreas Papandreou. Thus, the ruling elites found the chance to assume 'the features of a "broker" between international/European financial capital, on the one hand, and the government, on the other' (Fouskas and Dimoulas, 2013:144). This mode of transformation of the comprador class increased the level of dependence of the Greek economy, now not on the US post-war aid but on the cheap borrowing within the Eurozone instead. The various usurping activities of the European banks and other financial agencies were pernicious to any effort of 
re-formation of the real economy and industrial re-organization of Greece. In this sense, Simitis' 'modernization' phase was characterised by excessive corruption of those usurping elites that attained a mediatory role between the globalized financial capital and the domestic speculative and consumerist cycling of this capital. The seemingly high rates of growth of this period can only be conceived in parallel to a growth in the national debt of Greece. In its current crisis of debt, the burden of the recapitalization of the Greek banks is transferred to the taxpayer. At the same time and following subsequent bailouts, the Troika of international institutional creditors has implemented several rounds of austerity measures in Greece. The aftermath of these developments has been the utter impoverishment of the middle and lower classes.

In the final Chapter 7, the authors present the justification of their adamant view that the entry of Greece into the Eurozone has deteriorated the conditions of debt creation, but its origins should be traced through the concept of global, regional and domestic fault lines. These form a broader concept than uneven development, expressing the multifactorial dimension of debt creation and capitalist destruction of traditional socio-economic relations. In view of the catastrophic results of the subsequent rounds of austerity in the Greek society and economy, the authors propose a European and global cancelation of debt, promoted by socialist movements, especially in the periphery.

Overall, we have found this book to be a most useful addition to the toolkit of the future analyst of the Greek economic crisis. Offering unique insights on the political, geo-strategic and historical origins of this modern Greek tragedy, it provides a unique assessment of the country's global fault-lines. Despite its uniqueness and complexity, the book addresses large audiences of scholars, students and analysts, offering a uniquely insightful complementary perspective on the study of the Greek economic crisis. 